\title{
Gregor (Johann) Mendel (1822-1884)
}

\author{
Jules Janick \\ Department of Horticulture, Purdue University, West Lafayette, IN 47907
}

The origins of the modem science of genetics are to be found in a small monastery garden cultivated by one who truly worshiped at the altar of horticulture and science. Johann Mendel (the name "Gregor" was taken at his ordination), the child of peasants, was born in 1822 in Heinzendorf, a small village in a comer of Moravia. The boy, enamored of learning, was attracted to the monastery out of financial considerations. According to his autobiographical essay submitted for entrance to St, Thomas, the Augustine monastery of Brünn (now Brno, Czechoslovakia), his choice of vocation was influenced by his desire to be freed from the "perpetual anxiety about a choice of livelihood." He was accepted as a novice in 1843 and received a classical theological education at the local seminary. After ordination in 1847 , he spent a year as a parish priest, but "proved to be emotionally unsuited, beoming physically ill in the presence of sickness and pain. He was offered a post to teach mathematics and Greek in a local school at Zaire (1849-1850), a position in which he, although technically unqualified, performed with distinction. Despite his lack of university training, he took the qualifying examination for teachers, but failed the question that tripped him up was the classification of mammals - the specialty of the examiner.

His monastery sent Mendel to the Univ. of Vienna to spend 2 years studying science. In 1854 he was appointed supply (substitute?) teacher in Brünn Modern School, teaching physics and natural history to the lower school, a position he retained for 14 years. Incredibly, he again failed his accreditation exam, probably because of a dispute with his botany examiner, an event speculated to be connected with the initiation of his intensive experimental activities with peas the same year. His talents, however, were not lost on his fellow monks, who elected him prelate (for life) in 1868. The move proved to be a personal tragedy, for it caused him to withdraw from scientific work, and a bitter tax dispute between his monastery and the Austro-Hungarian government embittered the last decade of his life. He" died in 1884.

St. Thomas was not a cloistered retreat with silent, tonsured monks in sandals and hairshirts, but a vibrant community of scholars and artists. Mendel was neither ascetic

Received for publication 26 June 1990.
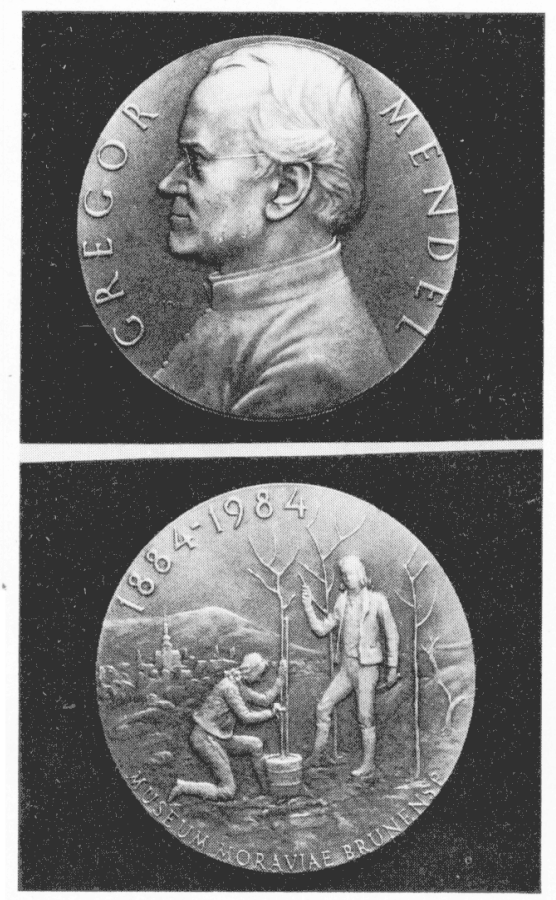

The Gregor Mendel medal sculpted by V. Kovanic on the 100th centenary of his death. The obverse side of the medal shows Mendel's father and a parish priest, J. Schreiber, grafting fruit trees commemorating Gregor Mendel's horticultural heritage and interests.

nor reclusive, and his writings are devoid of any religiosity whatsoever. Politically, he was antiauthoritarian - a 19th-century liberal. He loved good food (he grew quite corpulent) and fine cigars (20 a day). As prelate of a wealthy monastery, he lived the busy life of an administrator, housed in elegant style and traveling widely, serving on committees and boards. He managed farms, became chairman of the Moravian mortgage bank, and even founded a volunteer fire department. He served as officer of the Brünn Society for the Study of Natural Sciences, but, after 1870 , he switched allegiance to the Royal Agriculture Society, serving for 2 years as acting chairman. One of his duties was that of examiner for fruit and vegetable growers. Mendel's passions were science and agriculture. In addition to being a superb horticulturist, he was an accomplished meteorologist and wrote the definitive description of a tornado that tore through the monastery. Mendel kept records of such diverse phenomena as groundwater, sunspots, and ozone levels. Tragically, most of his scientific notes and correspondence were burned at his death.

Although his scientific career was unrecognized in his lifetime-due in part to his self-effacing style-his fame soared after the rediscovery of his famous paper on hybrids, and the legend of Mendel contributed much to the feverish genetic activity from 1900 to 1925 , probably making up for lost time. His subsequent fame as the "Father of $\mathrm{Ge}$ netics" has obscured the fact that Mendel was primarily a horticultural scientist. His paper, the most famous horticultural paper written, may be the most famous single paper in biology.

The story of the origin, neglect, and "rediscovery" of Mendel's great paper has become a legend in biology. An obscure "uneducated" monk in a backwater town in a corner of the Austro-Hungarian empire, working alone analyzing crosses of the garden pea, discovers the laws of inheritance. He performs precisely the correct experiments and derives precisely the correct interpretation. His evidence is published in a brilliant scientific paper that is a model of order and lucidity. Although the journal is obscure. it is exchanged around the world, but, alas, those who read it do not understand and those who should have read it and could understand, did not. Nevertheless, the paper is cited but the significance is missed. Mendel dies in 1884 unappreciated and unsung by the scientific and academic world. His paper is rediscovered in a rather shameful way by a distinguished academic (Hugo De Vries), who does not cite him. When credit is duly given, his paper creates a sensation.

The true story of Mendel is more surprising and intense than the legend. Posthumous studies by his biographers Hugo Iltis and Vitezslav Orel uncover a personality who was a truly creative thinker with profound scientific foresight. His stature continues to grow with the passage of time.

Although Mendel is principally remembered today for his classic paper on inheritance of the garden pea, he was a passionate horticulturist. As early as 1859 , Mendel exhibited vegetables in the Horticultural Section of the Moravian and Silesian Agricultural Society; he became a member in 1863 and subsequently supported regular exhibits of 
fruits, vegetables, and flowers in Brünn and offered prizes for the best improvements by hybridization.

In Autumn 1883, a few months before his death. he was awarded in absentia the medal of the Hietzug Horticultural Society for his exhibits of new cultivars of stone fruit seedlings, apple, and pear. He probably was the anonymous exhibitor of first prize for a collection of new cultivars of pears (Mendel was active as a member of the judging committee and never personally accepted any awards).

Surviving documents indicate that Mendel was actively involved in apple breeding. Recollections of the monastery gardener reveal that, in addition to Pisum and Hieracium hybridization, Mendel experimented with cucurbita and sedum, as well as pear, apples, and morels (nightshades). He was an active breeder of flowers, and a fuchsia was named 'Mendel' in his honor. Mendel conducted examinations in fruit growing for his horticultural society and organized the reclamation of denuded hills, the Spielburg, surrounding a local fortress. He was an expert apiculturist and was involved in hybridization and other areas of bee research. As an active member of the local apiculture society, Mendel contributed lectures and reports on his research and observations.

Gregor Mendel has turned out to be one of the great horticultural scientists of all time. His love of plants-his children-combined with brilliant insight enabled him to solve the riddle of heredity-a phenomenon that had baffled philosophers for 2500 years. His accomplishment places him in the pantheon of world-famous scientists. This great man and neglected genius remains as an inspiration for our Society. He is elected to the Horticulture Hall of Fame so that he will continue to serve as a role model for what horticultural science should be.

\section{References}

Corcos, A.F. and F.W. Monaghan. 1990. Mendel's work and its rediscovery a new perspective. Crit. Rev. Plant Sci. 9(3):197-200.

Folia Mendeliana. Supplemental ad Acts Musei Moraviae (vol. 23 was published in 1988). Published by the Moravian Museum Brno in the Panorama Publishing House, Czechoslovakia. Iltis, H. 1932 (reprinted 1966). Life of Mendel. George Allen \& Unwin, London. (Translated by Eden and Cedar Paul from Gregor Johann
Mendel, Leben, Werk and Wirkung. 1924. Julius Springer, Berlin.)

Mendel, G. 1866. Versuche über Pflanzan-Hybriden. (Experiments in plant hybrids). Verhandlungen des naturforschenden Vereines in Brünn 4(1865):347.

Mendel, G. 1869. Über einige aus kunstlicher. Befruchtung gewonnenen Hieracium-Bastarde, (On Hieracium-hybrids obtained by artificial fertilization). Verhandlungen des Naturforschenden Vereines in Brünn 8(1868):26-31.

Olby, R.C. 1966. Origins of Mendelism. Schocken Books, New York. (2nd cd., 1985, Univ. of Chicago Press.)

Orel, V. 1984. Mendel. Oxford Univ. Press, Oxford. U.K.

Ridley; M. 1984. The horticultural abbott of Brünn. New Sci. 5(Jan.):24-27.

Sosna, M. (ed.). 1966. G. Mendel memorial symposium 1865-1965. Proc. Symp., Brno, Czechoslovakia, 4-7 Aug. Academia, Publishing House of the Czechoslovak Academy of Sciences, Prague.

Stem, C. and E.R. Sherwood (eds.). 1966. The origin of geneties. A Mendel source book. W.H. Freeman, San Francisco.

Sturtevant, A.H. 1965. A history of genetics. Harper \& Row, New York.

Zirkel, C. 1935. The beginnings of plant hybridization. Univ. of Pennsylvania Press, Philadelphia. 